a sickly decaying odour, which can be detected a hundred or more yards away. While the scum is present, the native population avoids eating redcoloured reef fish and trevally, as well as certain surface fish, including the local barracuda. Often before the main spawning there is a minor event, when broken lengths of the hind parts become swollen with the reproductive elements and break off from the main body of the worms. At Ovalau Island there are regularly two risings of the worms each year, and at the second, or major, one the shallows over the reef contain masses of worms two to three feet deep in dense patches which are acres in extent. 'The phenomenon occurs between 3 and 4 a.m., when the massed worm-lengths rise out of the coral rock in thick rope-like columns; at this stage individuals may be up to two feet long, but soon after reaching the surface they break up into shorter lengths, and final complete disintegration, death and putrefaction follow soon after the coming of daylight and the rising of the sun. The local inhabitants await the event with great eagerness and collect the worms literally in tons with every kind of utensil that is suitable. The catch is considered a great delicacy and is usually boiled, though some is eaten raw. While it is usual for only two risings of palolo worms to occur at the end of each year, as is the case for the Tokau Reef area at Ovalau Island, there appear to be rare departures from this rhythm. One such is reported by Mr. Sorenson for Wakaya Island, about ten miles away from Ovalau Island, where four risings occurred in quick succession in 1953 and 1954, the last occurring in January after the third quarter of the moon.

\section{Forests and Climates in New Zealand}

As a result of an extensive survey of the forests and climates in the South Island of New Zealand by J. T. Holloway (Trans. Roy. Soc. New Zealand, 82, $2,329-410$; 1954), some interesting and important conclusions have been reached. An analysis of the indigenous forests has revealed many striking peculiarities of forest species and forest type distribution and behaviour in the Western Southland. These peculiarities are shown to be explicable in terms of a hypothesis which states, briefly, that the forests as a whole are in an unstable condition consequent on comparatively recent changes in regional climates ; and that, as a result, an active redistribution of species is in progress with the resultant development of a wide range of new, though unstable, forest types. This hypothesis appears to have a general application in the South Island. It is shown that the phenomena discussed in this contribution are by no means peculiar to New Zealand forests, but that valid reasons can be advanced for the prominence of certain features in New Zealand forests in comparison with those of other countries. The report is illustrated by some good aerial photographs.

\section{Further Education}

THE role of a regional council for further education in the British system of education is explained in the introduction to the seventh annual report of the Southern Regional Council for Further Education (pp. 30 ; Reading, October 1954). Apart from the necessary background work to provide information, the Council serves as a forum for deliberation and agreement by representatives of constituent authorities, universities, technical colleges, government departments, representatives from industry and other interested persons. The Council advises constituent education authorities. It secures general advice from among its own members, and special advice from the Academic Board and Advisory Committees. Among various items referred to in the report is a paper on full-time release for the technical training of operatives in the heating and ventilating trade, and the continuation of teacher-training courses for part-time and full-time teachers at technical institutions.

\section{"A New Development in Aids for Sub-normal Vision"}

REFERRING to the communication under this title by J. Lederer in Nature of November 20, 1954, p. 977, A. G. Bennett, 25 Brook Avenue, Wembley, Middlesex, has pointed out that there are two errors in the algebraic calculations. H. H. Emsley, 36 Meadow Way, Letchworth, has suggested that Mr. Lederer's third-order or Seidel equations are not sufficiently accurate, and that relaxation of accommodation and the assumption of the rotating eye are not justified. Mr. Lederer agrees that there were two algebraic errors in his calculations; revised equations and a new graph show, he claims, that there is no important change in the significant region. As regards the use of third-order equations, Mr. Lederer states that their accuracy is sufficient, as evidenced by the field properties of lenses made according to them. $\mathrm{He}$ adds that clinical study and experience of more than seven hundred cases of sub. normal vision have convinced him that there is no significant accommodative activity in the great majority of such patients, and that they engage in eye movements as well as head movements and movement of the printed matter. Many have obtained much better results with such single-lens microscopic lenses giving a large, well-corrected field of view than with compound magnifiers of equal or even higher magnification with a small corrected field.

\section{Nairobi Scientific and Philosophical Society: Officers for 1955}

THE eighth annual general meeting of the Nairobi Scientific and Philosophical Society was held in the Town Hall, Nairobi, on January 28, 1955, at which the following officers were elected for the forthcoming year: President, Mr. D. A. Davies ; Vice. Presidents, Dr. H. C. Pereira, Mr. H. W. Gill and Dr. H. H. Storey; Joint Honorary Secretaries, Mr. J. P. Henderson and Mr. J. Glover (P.O. Box 931, Nairobi); Honorary Treasurer, Mr. R. W. Walmsley; Honorary Librarian, Dr. D. W. Duthie ; Committee Members, Mr. R. W. Rayner, Mr. H. B. Stent, Mr. C. J. Martin, Mr. H. E. Watson and Dr. C. C. Webster.

\section{Conference on Cloud-Chamber Techniques}

A CONFEREnce on "Recent Developments in CloudChamber and Associated Techniques" will be held in the Department of Physics, University College, London, during March 24-26. There will be sessions devoted to the diffusion cloud chamber, the multiplate cloud chamber, the high-pressure cloud chamber, the bubble chamber, the interpretation of cloud chamber photographs, counter control systems for cloud chambers, and to overcompression and fast recompression techniques. The conference will be held under the joint auspices of the Physical Society and University College, London, and members of the Physical Society are invited to attend. Further 